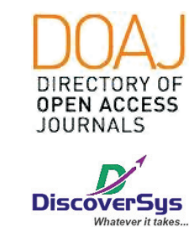

Published by DiscoverSys

\section{Pengaruh personal hygiene terhadap timbulnya akne vulgaris pada mahasiswa Program Studi Pendidikan Dokter angkatan 2014 di Fakultas Kedokteran Universitas Udayana}

\author{
I Putu Indra Ardhiyana Putra, ${ }^{1 *}$ Ketut Kwartantaya Winaya ${ }^{2}$
}

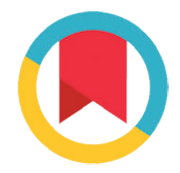

CrossMark

\title{
ABSTRACT
}

Introduction: The most common skin problem in teenager are acne vulgaris, could be define as an inflammatory skin disease that comes from pilosebaceous follicles. There are several factors that influence the occurrence of acne vulgaris such as increased production of sebum, clogging the follicle pilosebasea, increased colonization of bacteria Propionibacterium acnes, and individual level of hygiene. Personal hygiene can affect the onset of of skin diseases. Good hygiene couldt removes excess sebum without damaging the skin's protective lipids, and remove bacteria from the skin surface. Most teens, especially high school students often overlook the importance of maintaining the cleanliness of their faces. This study aims to determine the relationship between personal hygiene to complaints of acne vulgaris.
Method: Study design is a cross-sectional analytical study to find the relationship between personal hygiene with acne vulgaris. Data from this research using primary data obtained from the questionnaire With a total sample of 43. The sample was student of medical school, Faculty of Medicine, Udayana University.

Result: Based on the results of chi-square test between the level of personal hygiene and the incidence of acne vulgaris showed significant results ( $p=0.020$ ) so that there is a significant relationship between the level of personal hygiene with the incidence of acne vulgaris.

Conclusion: It concluded that students who have high levels of bad personal hygiene more experienced acne vulgaris. There is a significant correlation between maintaining personal hygiene with the onset of acne vulgaris.

Keywords: Third molar surgery, post-operative complications, reverse triangular flap

Cite This Article: Putra, I.P.I.A., Winaya, K.K. 2018. Pengaruh personal hygiene terhadap timbulnya akne vulgaris pada mahasiswa Program Studi Pendidikan Dokter angkatan 2014 di Fakultas Kedokteran Universitas Udayana. Intisari Sains Medis 9(2): 156-159. D0I: 10.1556/ism.v9i2.258

\section{ABSTRAK}

Latar Belakang: Akne vulgaris (AV) merupakan penyakit kulit yang meradang berasal dari folikel pilosebasea. Ada beberapa Faktor yang mempengaruhi terjadinya akne vulgaris antara lain terdapat peningkatan produksi sebum, penyumbatan folikel pilosebasea, peningkatan kolonisasi bakteri Propionibacterium acnes. Personal hygiene dapat berpengaruh terhadap timbulnya keluhan penyakit kulit seperti personal hygiene. Kebersihan yang baik adalah kebersihan yang menghilangkan kelebihan sebum tanpa merusak lipid pelindung kulit, dan menghilangkan bakteri dari permukaan kulit. Kebanyakan remaja khususnya pelajar SMA seringkali mengabaikan tentang pentingnya menjaga kebersihan wajah mereka. Penelitian ini bertujuan mengetahui hubungan antara personal hygiene terhadap keluhan acne vulgaris.
Metode: Penelitian ini merupakan jenis penelitian crossectional analitik untuk mencari hubungan antara personal hygiene dengan acne vulgaris. Data dari penelitian ini menggunakan data primer yang didapat dari hasil kuisioner Dengan jumlah sampel sebanyak 43. Sampel penelitian adalah mahasiswa program studi pendidikan dokter angkatan 2014 di Fakultas Kedokteran Universitas Udayana. Hasil: Berdasarkan hasil uji chi square antara tingkat personal hygiene dan kejadian akne vulgaris menunjukkan hasil yang signifikan ( $p=0,020$ ) sehingga terdapat hubungan yang signifikan antara tingkat personal hygiene dengan kejadian akne vulgaris.

Simpulan: Dapat disimpulkan bahwa Mahasiswa yang memiliki tingkat personal hygiene buruk lebih banyak mengalami acne vulgaris. Terdapat hubungan yang signifikan antara menjaga personal hygiene dengan timbulnya akne vulgaris $(p=0,020)$.

Udayana

indraardhiyana@gmail.com 


\section{PENDAHULUAN}

Banyak yang mengatakan dalam tubuh yang bersih, terdapat jiwa yang sehat, akan tetapi masih banyak juga orang yang sakit dan biasanya terjadi dikarenakan karena pola hidup mereka sendiri yang kurang baik dan kebiasaan yang kurang baik. Personal higiene yang kurang bagus yang dapat menimbulkan keluhan penyakit kulit seperti akne vulgaris. Beberapa upaya pemerintah atau instansi yang terkait sudah dilakukan untuk memerangi kurangnya kebersihan terhadap kulit guna untuk mengurangi keluhan-keluhan akne vulgaris.Upaya yang dilakukan pemerintah berupa pengadaan air bersih, pengadaan toilet-toilet layak pakai dan juga penyuluhan-penyuluhan hidup sehat dan bersih juga sudah banyak dilakukan oleh pemerintah dan instansi terkait.

Akne vulgaris menjadi masalah yang umum, terutama terjadi pada kalangan remaja. Belum ada data angka kejadian dan faktor resiko akne vulgaris di masyarakat. ${ }^{1}$ Selain masalah kosmetika, akne vulgaris bisa muncul karena bebrapa factor seperti produksi sebum, hiperkeratinisasi folikular, proliferasi Propionibacterium acnes (P. acnes) peradangan, dan genetika (gurdanc, 2005), selain itu kurang nya menjaga kebersihan kulit wajah maupun lingkungan juga bisa menimbulkan akne vulgaris. kebersihan kulit wajah dapat di jaga dengan cara meningkatkan personal higine kita seperti rajin membersihkan kamar mandi, rajin mengganti sepray kasur, sarung bantal tidur, cuci muka atau kulit wajah setelah bepergian, setelah kontak langsung dengan sinar matahari, polusi, setelah menggunakan make up, dan masih banyak lagi. Angka kejadiannya akne vulgaris berkisar $85 \%$ dan terbanyak pada usia muda. Pada umumnya insiden akne terjadi pada usia 14-17 tahun pada wanita dan 16-19 tahun pada laki-laki, dengan lesi predominan adalah komedo dan papul. ${ }^{1,3}$

Kulit merupakan pembungkus yang elastik yang melindungi tubuh dari pengaruh lingkungan. Kulit juga merupakan alat tubuh yang terberat dan terluas ukurannya, yaitu $15 \%$ dari berat tubuh dan luasnya $1,50-1,75 \mathrm{~m}^{2}$, rata-rata tebal kulit 1-2 mm, paling tebal $(6 \mathrm{~mm})$ ada ditelapak tangan dan kaki paling tipis $(0,5 \mathrm{~mm})$ ada di penis. Selain itu Kulit adalah salah satu bagian tubuh yang cukup sensitif terhadap berbagai macam penyakit. Lingkungan yang kotor akan menjadi sumber munculnya berbagai macam penyakit kulit. ${ }^{2}$ Faktor- faktor yang mempengaruhi tingginya prevalensi penyakit kulit adalah iklim yang panas dan lembab, kebersihan perorangan yang kurang baik yaitu kebersihan kulit, kebersihan rambut dan kulit kepala, kebersihan kuku, intesitas mandi selain itu faktor ekonomi yang kurang memadai juga mempengaruhi. Selain factor factor tersebut ada juga factor lain yang akan menimbulkan keluhan penyakit kulit seperti personal higine yang kurang memadai. Penelitian ini bertujuan untuk melakukan evaluasi hubungan antara personal hygiene terhadap akne vulgaris pada mahasiswa program studi pendidikan dokter Fakultas Kedokteran, Universitas Udayana angka$\tan 2014$.

\section{METODE}

Penelitian ini merupakan penelitian analitik karena dalam pelaksanaannya meliputi pengumpulan data, analisis dan interpretasi dari data yang diperoleh. Penelitian ini dilakukan dengan menggunakan pendekatan cross-sectional, dimana proses penelitian menggunakan data primer untuk mengetahui pengaruh personal hygiene terhadap keluhan akne vulgaris pada mahasiswa program studi pendidikan dokter angkatan 2014, Fakultas Kedokteran Universitas Udayana. Penelitian ini menggunakan 43 subjek penelitian yang dicari melalui metode konsekutif. Data kebersihan diri dan kejadian akne diperoleh melalui kuesioner kebersihan yang telah dilakukan validasi. Analisis data menggunakan bantuan program Statistical Package for Social Science version 17.0, uji chi-square digunakan untuk mengetahui hubungan antara personal hygiene dan akne vulgaris.

\section{HASIL}

Data dari penelitian ini merupakan data primer yang di dapat dari hasil kuisioner yang di sebar pada mahasiswa program studi pendidikan dokter angkatan 2014 di Fakultas Kedokteran Universitas Udayana. Subjek dari penelitian ini adalah mahasiswa angkatan 2014 program studi pendidikan dokter yang bersedia menjadi sampel penelitian dengan jumlah sampel sebanyak 43 orang. Karakteristik subjek penelitian dapat dilihat pada tabel 1.

Berdasarkan tabel 1, Karakteristik dari subjek terdiri atas usia dan jenis kelamin. Responden laki-laki berjumlah 17 orang $(39,5 \%)$ dan perempuan sebanyak 26 orang (60,5\%). Rentang usia responden adalah 17-21 tahun. Responden paling banyak berusia 19 tahun, yaitu sebanyak 25 orang $(58,1 \%)$. Rata-rata usia responden adalah 18 tahun. Kebersihan responden diukur dengan menjawab pertanyaan kuesioner. Berdasarkan hasil perhitungan statistika didapatkan rata-rata nilai kebersihan responden adalah 7,0155. Klasifikasi personal hygiene pada penelitian ini dikelompokkan menjadi dua derajat yaitu derajat kurang (skor 1-7), dan derajat baik (skor 8-10). Responden yang 
Tabel 1 Karakteristik Subjek Penelitian

\begin{tabular}{llcc}
\hline Karakteristik Responden & Jumlah $(\mathbf{n}=\mathbf{4 3})$ & Persen $(\%)$ \\
\hline \multirow{2}{*}{ Jenis Kelamin } & Laki-laki & 17 & 39,5 \\
Usia & Perempuan & 26 & 60,5 \\
& 17 & 1 & 2,3 \\
\multirow{4}{*}{ Kebersihan } & 18 & 16 & 37,2 \\
\multirow{3}{*}{ Kejadian Akne } & 19 & 25 & 58,1 \\
& 21 & 1 & 2,3 \\
& Baik & 25 & 58,1 \\
& Buruk & 18 & 41,9 \\
& Ya & 33 & 76,7 \\
& Tidak & 10 & 23,3 \\
\hline
\end{tabular}

Tabel 2 Tabulasi silang dan uji chi-square antara jenis kelamin dan kebersihan terhadap kejadian akne

\begin{tabular}{|c|c|c|c|c|c|}
\hline \multirow[b]{2}{*}{ Variabel } & & \multicolumn{2}{|c|}{ Kejadian akne } & \multirow[b]{2}{*}{ Total } & \multirow[b]{2}{*}{ Nilai p } \\
\hline & & Ya & tidak & & \\
\hline \multirow{2}{*}{ Jenis Kelamin } & Laki-laki & 14 & 3 & 17 & \multirow{2}{*}{0,481} \\
\hline & Perempuan & 19 & 7 & 26 & \\
\hline \multirow{2}{*}{ Kebersihan } & Baik & 16 & 9 & 25 & \multirow{2}{*}{0,020} \\
\hline & Buruk & 17 & 1 & 18 & \\
\hline
\end{tabular}

memiliki kebersihan baik sebanyak 25 orang $(58,1 \%)$ dan kebersihan buruk sebanyak 18 orang $(41,9 \%)$. Responden yang mengalami akne sebanyak 33 orang $(76,7 \%)$. Hubungan antara jenis kelamin, tingkat kebersihan terhadap akne vulgaris dapat dilihat pada tabel 2.

Berdasarkan tabel 2, Pada penelitian ini didapatkan 14 orang laki-laki mengalami kejadian akne vulgaris sedangkan 3 orang tidak mengalami kejadian akne vulgaris. Pada perempuan sebanyak 19 orang mengalami kejadian akne vulgaris sedangkan 7 orang tidak mengalami kejadian akne vulgaris. Berdasarkan hal tersebut maka dilakukan uji chi-square terhadap jenis kelamin dengan kejadian akne untuk mengetahui adanya hubungan antara tingkat kebersihan dengan kejadian akne dan didapatkan hasil nilai $\mathrm{p}=0,481(\mathrm{p}>0,05)$, sehingga dapat disimpulkan tidak terdapat hubungan yang bermakna antara jenis kelamin dan kebersihan diri.

Pada variabel tingkat kebersihan, dari 25 subjek dengan tingkat kebersihan baik, 16 orang diantaranya mengalami kejadian akne vulgaris sedangkan 9 orang tidak mengalami kejadian akne vulgaris. Pada subjek yang tingkat kebersihan nya buruk dengan jumlah 18 orang, 17 diantaranya mengalami kejadian akne vulgaris sedangkan hanya 1 orang yang tidak mengalami kejadian akne vulgaris. Berdasarkan hal tersebut maka dilakukan uji chi-square terhadap tingkat kebersihan dengan kejadian akne untuk mengetahui adanya hubungan antara tingkat kebersihan dengan kejadian akne, dan di dapatkan hasil $\mathrm{p}=0,020(<0,05)$, sehingga dapat disimpulkan terdapat hubungan yang bermakna antara kebersihan diri dengan akne vulgaris. (Tabel 2)

\section{PEMBAHASAN}

Berdasarkan Hasil uji chi square antara tingkat personal hygiene dan kejadian akne vulgaris menunjukkan hasil yang signifikan $(\mathrm{p}=0,020)$ sehingga terdapat hubungan yang signifikan antara tingkat personal hygiene dengan kejadian akne vulgaris.

Personal hygiene adalah bagian penting dari menjaga atau meningkatkan kesehatan kulit, khususnya integritas penghalang kulit. Akne vulgaris atau yang biasa di sebut jerawat adalah penyakit kulit kronis yang di akibatkan karena adanya peradangan yang bisa di tandai dengan adanya pustule, nodul, papul, komedo dan kista yang biasanya muncul pada kelenjar sebasea berukuran besar seperti wajah, punggung, dan dada. ${ }^{4}$

Berdasarkan studi yang di lakukan oleh Hertanto (2013) studi mengenai tingkat kebersihan wajah dengan kejadian akne vulgaris pada siswa SMA menyatakan terdapat adanya hubungan yang signifikan antara derajat kebersihan wajah dengan kejadian akne vulgaris. ${ }^{5}$ Studi lain yang dilakukan oleh Utami (2008) mengenai hubungan tingkat stress dan kebersihan diri dengan kejadian akne vulgaris menyatakan yang sama yaitu terdapat adanya hubungan yang signifikan antara derajat kebersihan wajah dengan kejadian akne vulgaris. ${ }^{5,6}$

Penelitian ini sesuai dengan teori bahwa makin sering seseorang membersihkan wajah, maka makin rendah angka kejadian akne vulgaris karena membersihkan wajah secara teratur dapat mengurangi minyak yang berlebih serta mengangkat sel kulit mati pada wajah serta membersihkan wajah adalah bagian dari menjaga personal hygiene. ${ }^{7}$

Penelitian ini tidak terlepas dari berbagai keterbatasan seperti variable dan jumlah sampel. Selain itu karena data yang di gunakan adalah data primer yang diambil dari kuisioner sehingga mengakibatkan adanya keterbatasan dalam pengolahan variable perancu dan keterbatasan dalam penyusunan kuisioner. Selain itu terdapat juga faktor-faktor lain yang tidak dapat diteliti yang mungkin akan mempengaruhi hasil penelitian.

\section{SIMPULAN}

Terdapat hubungan yang bermakna antara kebersihan diri dengan akne vulgaris, namun tidak terdapat adanya hubungan yang bermakna antara jenis kelamin dengan akne vulgaris. 


\section{DAFTAR PUSTAKA}

1. Tjekyan S. Kejadian dan Faktor Resiko Akne Vulgaris. Mediana Medika Indonesia. 2009; 43(1):37 - 43.

2. Sinclair W, Jordan HF. Acne guideline 2005 update. S Afr Med J. 2005;95(11):881-892.

3. Abdulmajeed A, Yousef AAT, Alhazanni Y, Alhowaish N, Eid NA, Alhozaimi Z, Saleh WA, et al. Prevalence, level of knowledge and lifestyle association with acne vulgaris among medical students. Journal of Dermatology \& Dermatologic Surgery. 2017;21(2):58-61.

4. Anjali $M$, Acne Vulgaris: a review. Medicine. 2017;45(6):386-389

5. Hertanto. Hubungan antara kebersihan wajah dengan kejadian akne vulgaris (skripsi). Universitas muhamadiyah: Surakarta. 2013
6. Utami. Hubungan tingkat stress dan kebersihan diri dengan kejadian akne vulgaris. (skripsi). Universitas airlangga: airlangga university library. 2008.

7. Ghodsi SZ, Orawa H, Christos C. prevalence, severity, and severity risk factor of acne in high school pupils: A community-based study. Journal of Inverstigative Dermatology. 2009;129(9):2136-2141.

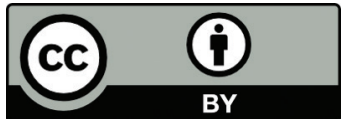

This work is licensed under a Creative Commons Attribution 